\begin{tabular}{llr} 
KULTURA & POLSKA A KADEMIA NAUK & ISSN 0023-5172 \\
i & KOMITET SOCJOLOGI & \\
SPOLECLENSTWO & $\begin{array}{l}\text { INSTYTUT STUDIÓW POLITYCZNYCH } \\
\text { 2020, nr 3 PROJEKTOWANIE DZIECIŃSTWA }\end{array}$ & \\
\hline
\end{tabular}
$\begin{array}{lllllllll}A & R & T & Y & K & U & Ł & Y\end{array}$
I
$\begin{array}{llllllll}\mathrm{R} & \mathrm{O} & \mathrm{Z} & \mathrm{P} & \mathrm{R} & \mathrm{A} & \mathrm{W} & \mathrm{Y}\end{array}$

AGATA ŻBIKOWSKA

Uniwersytet Warszawski

\title{
CZAS WOLNY NASTOLATKÓW W PERSPEKTYWIE TEORII SOCJOLOGICZNEJ
}

Podejście do czasu wolnego ulegało znacznym przemianom w ciągu ostatnich kilkudziesięciu lat, następowały one wraz z przekształcaniem się rynków pracy. W Polsce wiele zmian pojawiło się w tej sferze po roku 1989, związane były z wejściem w ustrój kapitalistyczny. W refleksji teoretycznej na rodzimym gruncie czas wolny definiowany jest zazwyczaj jako przeciwieństwo pracy, jako czas wolności i swobody (Wnuk Lipiński 1975, 1981; Fatyga 2012; Szafraniec, Boni 2011), a sposób jego spędzania jako element wybranego stylu życia i wyznacznik prestiżu (Domański 1999; Jacyno 2007; Zarycki 2008). Opiszę tutaj też inne możliwe sposoby definiowania czasu wolnego. Powszechnie używane pojęcie „czas wolny” nie odsyła bowiem w wystarczającym stopniu do faktycznie zachodzących zjawisk i istotnych praktyk społecznych. Nie pozwala uchwycić złożoności sposobów wykorzystania czasu wolnego od pracy czy szkoły ani tym bardziej nie bierze pod uwagę jego ograniczeń i uwikłań. Badacz zatem musi najpierw odpowiedzieć sobie raczej nie na pytanie „co badani robią w czasie wolnym", lecz czym jest czas wolny i czy istnieje w taki sposób, w jaki przywykliśmy o nim myśleć. Moje rozważania zmierzają do rozpoznania specyfiki czasu wolnego dzieci i młodzieży i wskazania uwarunkowań jego badania.

Czas wolny nastolatków to temat stosunkowo rzadko podejmowany przez polskich badaczy, którzy skupiają się przede wszystkim na proble- 
mach i zagrożeniach dotykających tę grupę wiekową oraz kwestiach związanych z edukacją i postawami obywatelskimi. Przedstawię tutaj podejścia teoretyczne pozwalające w możliwie najpełniejszym stopniu sproblematyzować tę kwestię.

\section{CZAS WOLNY A PRACA — ZMIANY W PODEJŚCIU BADAWCZYM}

Pojęcie czasu wolnego wykształciło się $\mathrm{w}$ okresie rewolucji przemysłowej, w ścisłej relacji do pojęcia i realiów rynku pracy (Walvin 1978; Cross 1990; Rojek 1995). Czas ów ujmowany z perspektywy jednostki pozwalał na samorealizację, z punktu widzenia społeczeństwa natomiast był okazją do odpoczynku i regeneracji pozwalającej na efektywne podjęcie dalszych zajęć zarobkowych. Nie był już powiazany ze świętami religijnymi, jak w epoce przedindustrialnej, a stał się wynikiem kompromisu między pracownikami a pracodawcami i coraz częściej podlegał regulacjom wprowadzanym przez władze poszczególnych państw. W 1800 roku na wsi angielskiej było przeciętnie trzynaście dni wolnych, poświęcanych na obchody świąteczne, picie, tańce i gry, a już w 1870 roku pozostał tylko jeden taki dzień (zob. Cross 1990), Jednak wkrótce ta tendencja się odwróciła. Wolną niedzielę po raz pierwszy wprowadzono w Wielkiej Brytanii w XIX wieku. Część właścicieli fabryk zgodziła się na takie rozwiązanie z przyczyn praktycznych - chcieli, aby w poniedziałek robotnicy stawiali się w pracy trzeźwi i wypoczęci (Rybczynski 1991). Pięciodniowy dzień pracy pierwszy raz ustanowiono w 1908 roku w Stanach Zjednoczonych, a w Polsce dwudniowy weekend wprowadzano od lat siedemdziesiątych stopniowo, począwszy od „wolnych sobót”. Podobnie było z godzinami pracy. Początkowo mężczyźni, kobiety i dzieci pracowali w fabrykach nawet w wymiarze czternastu godzin dziennie, ale stosunkowo szybko czas ten zaczął ulegać skróceniu (w przypadku dzieci na korzyść edukacji) (Cross 1990). Początek XX wieku to już nie tylko wolne od pracy godziny czy dni, ale pojawienie się mody na wyjazdy wakacyjne, również wśród rozwijającej się i coraz bogatszej klasy średniej. Pracodawcy chętniej zgadzali się na urlop niż skrócenie czasu pracy, tym bardziej że w wielu przypadkach zbiegał się on z przerwami w pracy zakładu.

Czas wolny stawał się polem biznesu. Czytanie książek i prasy, wyjścia do muzeów i galerii ludzkich osobliwości (tzw. freak shows), udział w potańcówkach, wypady do kina, uprawianie sportu - wszystkie te zajęcia wymagały nakładów finansowych i dla rosnącej grupy ludzi stawały się okazją do zarobku. Biznes ten był jednak powiązany głównie z miejskością, bo to w miastach przede wszystkim działały opery, teatry, muzea, 
kawiarnie i kluby. Na wsiach czas pracy i odpoczynku wyznaczały pory roku, a ze względu na niski poziom wykształcenia mieszkańców oraz ubogą ofertę sposoby spędzania czasu wolnego od zajęć gospodarskich były stosunkowo ograniczone.

W epoce nowoczesnej, wraz z pojawieniem się fordowskiego systemu pracy, wiele się zmieniło. Ogromne rzesze ludzi po raz pierwszy w historii podejmowały pracę jednostajną i niedającą perspektyw rozwoju, ale jednocześnie dobrze płatną i stabilną. Sposoby spędzania czasu wolnego, które wykształciły się w tamtym okresie, miały więc ulżyć monotonii, jakiej doświadczano $\mathrm{w}$ pracy. Były one ściśle powiązane $z$ konsumpcją. Lata pięćdziesiąte XX wieku w Stanach Zjednoczonych to złota era hollywoodzkiego kina, a także czas gwałtownego rozwoju telewizji (od połowy tej dekady również w kolorze). Powszechnie dostępna staje się kolorowa prasa, popularność zyskują komiksy, gry planszowe (scrabble, monopol) czy pełnometrażowe filmy animowane dla najmłodszych odbiorców. Gwałtownie rozwija się przemysł muzyczny, głównie gałąź muzyki rozrywkowej. Pojawiają się masowo produkowane zabawki dla dzieci. To również okres rozwoju reklamy oraz branży turystycznej. Podobne zjawiska zachodziły wówczas w Europie Zachodniej.

Kulturę nastolatków od początku cechowały określone formy konsumpcji, które stawały się wyznacznikami tożsamości grupowej — stroje, fryzury, posiadane przedmioty świadczyły o przynależności do grupy lub statusie nastolatka. W miarę jak młodzież odsuwano od pracy zarobkowej ku edukacji, grupa ta dyspopnowała coraz mniejszymi zasobami finansowymi. Nie oznacza to jednak, że rynek produktów dla dzieci i młodzieży nie istniał. Wprost przeciwnie - w latach 1900-1930 działy literatury dziecięcej, mody, zabawek i innych produktów pojawiły się we wszystkich większych sklepach w Stanach Zjednoczonych (Cook 2004). Od lat pięćdziesiątych rozrastał się rynek przedmiotów przeznaczonych dla dzieci i nastolatków, takich jak przenośne telewizory, gry wideo i komputerowe, sprzęt muzyczny, ubrania, samochody, a w późniejszym okresie telefony komórkowe, aplikacje i in. (Milner 2016). W życiu społecznym pojawiły się wydarzenia towarzyskie organizowane specjalnie dla tej grupy wiekowej, takie jak bale uczniowskie czy studniówki. Rozwijający się rynek produktów dla dzieci i młodzieży w ogromnym stopniu był powiązany z potrzebami realizowanymi poza szkołą.

Dla klasyków myśli społecznej - Karola Marksa, Émile’a Durkheima (1999) czy Maksa Webera (1994) — czas wolny stanowił zagadnienie drugorzędne wobec czasu pracy. Ich koncepcje stały się inspiracją dla badaczy zagadnienia w późniejszych latach. Na przykład prace Marksa nie doty- 
czyły bezpośrednio czasu wolnego, lecz podejmowana w nich tematyka dynamiki walk klasowych obejmowała całokształt życia człowieka i stała się ważnym nurtem w późniejszych badaniach czasu wolnego ${ }^{1}$. Niezwykle istotna dla późniejszych rozważań okazała się również przedstawiona przez Webera (2002) wizja klas i warstw społecznych. Choć towarzysząca jej koncepcja stylów życia dotyczyła przede wszystkim wyznaczników powiązanych z rodzajami wykonywanej pracy i położeniem gospodarczym, styl życia nie zależał wyłącznie od wysokości środków finansowych pozostających do dyspozycji jednostki, lecz również od statusu, praw i stosunków społecznych, a zatem był powiązany z płcią, pochodzeniem etnicznym czy wiekiem. W późniejszym okresie stworzone przez Webera pojęcie stylu życia zostało odniesione do wszystkich dziedzin życia człowieka. Objęło również czas wolny.

Jednym $z$ pierwszych socjologów ściśle specjalizujących się $w$ tematyce czasu wolnego był francuski badacz Joffre Dumazedier. Zdefiniował on to pojęcie jako czas, który pozostaje po wypełnieniu obowiązków zawodowych, domowych i szkolnych, przeznaczony na wypoczynek, rozrywkę oraz rozwój osobowości (Dumazedier 1974, s. 71). Z inicjatywy Dumazediera i Szalaia w latach pięćdziesiątych XX wieku utworzono międzynarodową grupę badawczą zajmującą się tą problematyką (zob. Truszkowska-Wojtkowiak 2012). W późniejszych latach czas wolny stał się przedmiotem badań wielu socjologów, antropologów, psychologów i ekonomistów, którzy zajmowali się nie tylko powiązaniem czasu wolnego z czasem pracy, ale również nowymi formami czasu wolnego (Stebbins 2007), sposobami doświadczania czasu wolnego (Neulinger 1974), negatywnymi aspektami czasu wolnego (Rojek 2000) czy wpływem turystyki na mieszkańców regionów turystycznych, ekonomię i środowisko (MacCannell 2002; Urry, Larsen 2011). Refleksja nad czasem wolnym znalazła miejsce również w myśli feministycznej (Scraton 1992; Wearing 1998). Dziś socjologia czasu wolnego stanowi prężnie rozwijającą się subdyscyplinę.

Polscy badacze początkowo rozpatrywali zagadnienie czasu wolnego przede wszystkim w kontekście zagadnień polityki społecznej. Aleksan-

\footnotetext{
${ }^{1} \mathrm{Z}$ koncepcji tego filozofa inspiracje czerpali się chociażby John Clarke i Chas Critcher, którzy w książce The Devil Makes Work (1985) argumentowali, że kapitalizm nadaje kształt zarówno pracy, jak i czasowi wolnemu. Widzieli oni rozrywkę jako nagrodę, na którą trzeba zasłużyć. Możliwości spędzania czasu wolnego były, według ich opinii, mocno skomercjalizowane, a dostęp do dóbr rozrywkowych w społeczeństwie nierównomierny. Struktura klasowa odgrywała ogromną rolę w doborze zajęć czasu wolnego, a udział w nich przyczyniał się do utrzymania nierówności społecznych. Echa tych rozważań stanowią do dziś ważny element debaty na temat funkcji czasu wolnego w społeczeństwie.
} 
der Kamiński (1965) stosował w pracy badawczej koncepcję Dumazadiera, zwracając przy tym uwagę na wychowawcze aspekty czasu wolnego i wskazując na jego edukacyjny potencjał, istotny zwłaszcza dla młodzieży czy osób o mniej uprzywilejowanej pozycji społecznej (robotnicy, rolnicy). Ważnym obszarem badawczym stały się instytucje kultury, a także problematyka uczestnictwa w kulturze (Wnuk-Lipiński 1975, 1981; Danecki 1970; Czajka 1974) oraz relacja między czasem pracy a czasem wolnym. Edmund Wnuk-Lipiński (1975, s. 16) szczególną uwagę zwracał na problem wyobcowania człowieka $\mathrm{w}$ miejscu pracy i fakt, że swobody mógł on doświadczyć wyłącznie poza tym miejscem: „Mówi się o alienacji procesu pracy, o tym, że człowiek staje się bezwolną i podporządkowaną częścią przerastającego go organizmu gospodarczego, że właśnie w czasie wolnym ma on szanse odnaleźć siebie, być prawdziwie wolnym, uniezależnionym od coraz surowszych rygorów nowoczesnej organizacji pracy". Takie podejście do czasu wolnego w stosunkowo mało zmienionej postaci przetrwało w polskiej socjologii do dziś. Na przykład „czas dla siebie” - pojęcie zaproponowane przez Barbarę Fatygę (2012) na użytek portalu Obserwatorium Żywej Kultury — to czas, który jednostka uznaje za: „wyjęty spod większości presji życiowych (dorabianie, codzienne czynności domowe, codzienne zaopatrzenie domu) i pozostający w jej swobodnej dyspozycji”. Można postrzegać tę definicję jako uwspółcześniony odpowiednik definicji Dumazadiera. Badaczka zauważa jednak, że czas ten podlega presji społecznej, co jest uzupełnieniem i uściśleniem definicji francuskiego badacza. Nieco inną definicję przyjęto w badaniach budżetu czasu Polaków. Renata Siemieńska (2006) twierdzi, że sposoby użytkowania czasu zależą od wielu czynników, wśród których wymienia się między innymi płeć, fazę cyklu życiowego, aktywność zawodową, wzory kulturowe i więzi społeczne. Badania GUS w ogóle nie wyodrębniają kategorii „czas wolny”, lecz dzielą zajęcia wykonywane poza pracą na kilka kategorii, takich jak: „dobrowolna praca w organizacjach i poza nimi”, „życie towarzyskie i rozrywki”, „uczestnictwo w sporcie i rekreacji”, „zamiłowania osobiste - hobby i korzystanie $z$ komputera” oraz „korzystanie ze środków masowego przekazu" ${ }^{2}$.

W ciągu ostatnich kilkunastu lat ogromne zmiany technologii i rynku pracy wymusiły zmianę organizacji czasu, który przywykliśmy nazywać „wolnym”. Po pierwsze, zastosowanie na szeroką skalę komputerów i internetu w miejscach pracy znacznie ułatwiło pracę zdalną. Według danych

2 Zob. Budżet czasu ludności 1996, GUS, Warszawa 1998; Budżet czasu ludności 1.VI.2003-31.V.2004, GUS, Warszawa 2005; Budżet czasu ludności 2013, GUS, Warszawa 2015. 
Eurostatu ${ }^{3}$ odsetek Polaków pracujących $z$ domu był najwyższy w 2015 ro$\mathrm{ku}$, kiedy osiągnął poziom $5,6 \%$, by następnie nieco spaść. Przed pandemią wynosił 4,6\% - nieco poniżej średniej europejskiej (5,3\%), a jednocześnie pokaźna była liczba Polaków pracuje w firmach jednoosobowych (ok. 3 mln w 2018 r. $^{4}$ ). Obydwa te rozwiązania wymuszają nienormowany czas pracy, bez wyraźnie wyznaczonego końca. Urządzenia telekomunikacyjne $\mathrm{i}$ informatyczne pozwalają na kontakt $z$ pracownikami poza godzinami pracy. Zwłaszcza upowszechnienie się smartfonów przyczyniło się do zaniku podziałów na czas wolny i czas pracy (Belkin, Becker, Conroy 2020). Przeprowadzane przez firmy komercyjne sondaże sugerują, że odpowiadanie na e-maile lub odbieranie telefonów służbowych poza godzinami pracy jest raczej codziennością niż wyjątkiem - robi to $60-70 \%$ Polaków ${ }^{5}$. Wiele osób zabiera narzędzia pracy również na wakacje, pozostając w tym czasie do dyspozycji pracodawców lub zleceniodawców, co zakłóca dobrostan pracowników, może powodować wyższy poziom stresu oraz problemy ze snem (Barber, Santuzzi 2017).

\section{CZAS WOLNY — ZMIANY FORM I AKTYWNOŚĆ NAJMŁODSZYCH}

Również w przypadku młodzieży coraz trudniejsze staje się rozróżnienie czasu wolnego i czasu nauki. Podkreślający znaczenie samodyscypliny i aspiracji rodzice (Gdula 2018), zwłaszcza ci z polskiej klasy średniej, wymagają od dzieci uwzględniania tych wartości także przy wyborze zajęć dodatkowych. Młodzi ludzie spędzają zatem wolny czas w taki sposób, aby w przyszłości zwiększyć swoje szanse na coraz trudniejszym i bardziej wymagającym rynku pracy. Te zajęcia dodatkowe często wymagają sporego wysiłku (np. lekcje języka) i chociaż zaliczane są do czasu wolnego, w rzeczywistości są rodzajem pracy. Istnieje ogromna społeczna presja na „bycie zajętym", najlepiej w sposób produktywny (Rojek 2000). Lenistwo czy nuda nie są pożądane i należy ich unikać za wszelką cenę. Nawet pozorowane

${ }^{3}$ Eurostat, 2015, 2019 (https://ec.europa.eu/eurostat/web/products-eurostat-news//DDN-20180620-1 [dostęp: 10.09.2020]).

${ }^{4}$ Miazek Katarzyna, 2018, Rekordowa liczba jednoosobowych firm $w$ Polsce (https://www.skar biec.biz/inne/rekordowa-liczba-jednoosobowych-firm-w-polsce.html [dostęp 21.10.2019]).

${ }^{5}$ Michael Page, 2018, Zacierajace się granice pomiędzy praca a życiem prywatnym (https://www. michaelpage.pl/advice/career-advice/work-life-balance/zacierające-się-granice-pomiędzy-pr acą-życiem-czy-naprawdę [dostęp: 10.09.2020]); Business Insider, 2020, „Wylogować się do życia" łatwo nie jest. Pracujemy nawet na wakacjach (https://businessinsider.com.pl/rozwoj-osob isty/rownowaga/polacy-pracuja-nawet-na-wakacjach-raport-devire/dj8dce8 [dostęp: 10.09. 2020]). 
działanie wydaje się lepsze niż brak działania, stąd zjawisko inteligentnej nudy (smart boredom) (Krajewski 2013), która sprawia, że jesteśmy zajęci nawet wtedy, kiedy nic nie robimy.

Jeśli chodzi o polskie dzieci, to spędzają one w szkole około 650 godzin rocznie, podczas gdy średnia w krajach OECD (2016) wynosi 800 godzin. Liczba dni nauki w roku szkolnym w Polsce to około 180. Najmniej czasu w ławce spędzają dzieci w klasach 1-3, w kolejnych latach liczba godzin lekcyjnych systematycznie wzrasta. Należy pamiętać o kilku czynnikach, które wpływają na rzeczywisty rozmiar czasu spędzanego przez młodych ludzi na nauce. Badanie OECD bierze pod uwagę wyłącznie przedmioty obowiązkowe i szkoły publiczne. Oznacza to, że zajęcia dodatkowe i fakultatywne oferowane przez szkołę nie są liczone do liczby godzin, choć młodzież coraz częściej z nich korzysta. Po drugie, w szkołach niepublicznych siatka zajęć, zwłaszcza w dużych miastach, często wygląda inaczej - godzin lekcyjnych jest więcej, a oferta zajęć dodatkowych jest bardziej rozbudowana. Po trzecie, dane te nie obejmują prac domowych ani korepetycji. I wreszcie po czwarte - liczba godzin spędzanych w szkole wydłużyła się w Polsce po reformie szkolnictwa, zwłaszcza w klasach siódmych i ósmych, gdzie konieczność realizacji podstawy programowej ze wszystkich przedmiotów (bez dodatkowych godzin języka w szkołach dwujęzycznych) wymaga 31 godzin nauki szkolnej tygodniowo, a więc około 797 godzin w ciągu roku szkolnego. Należy również pamiętać o tym, że dłuższy czas pracy rodziców oznacza często więcej godzin przebywania w szkole dla dzieci. Aby uniknąć tego, że potomstwo przebywa samo w domu, rodzice decydują się na wykupienie dodatkowych zajęć edukacyjnych. Nie wszystkie są zgodne $z$ faktycznymi zainteresowaniami nastolatków niektóre mają służyć jako „przechowalnia” dzieci do czasu aż rodzice wrócą z pracy. Tematyka zajęć ma znaczenie drugorzędne.

Pozostały po pracy i szkole czas wolny staje się coraz bardziej zorganizowany i przeznaczony na realizację rozlicznych projektów. Wprowadzony przez Roberta Stebbinsa (2007) podział na swobodny czas wolny (casual leisure) oraz poważny czas wolny (serious leisure) dobrze oddaje tę zmianę. Pojęcie swobodnego czasu wolnego obejmuje wszystko to, co zwykliśmy potocznie uznawać za zajęcia służące odpoczynkowi. Jest to więc działalność rozrywkowa, która nie wymaga żadnych kompetencji — oglądanie telewizji, czytanie książek lub gazet, słuchanie muzyki, gra na komputerze. Poważny czas wolny zaś to zajęcia zorganizowane lub wymagające kompetencji, na przykład nauka języków obcych, przygotowania do amatorskiego maratonu, działalność artystyczna, ale również wolontariat, działalność proekologiczna $\mathrm{i}$ in. Wiele $\mathrm{z}$ tych zajęć wymaga systematycznej pracy, 
a w niektórych przypadkach może również generować dochód (na przykład w przypadku produkowanej amatorsko biżuterii), choć wciąż mieszczą się w definicji hobby.

Zjawisko prosumpcji opisane przez Alvina Tofflera (1986) kieruje uwagę na jeszcze jeden obszar zacierania się granic między czasem wolnym a czasem pracy. Prosument jest osobą jednocześnie konsumującą i tworzącą produkty. Warto przy tym pamiętać, że zajęcia czasu wolnego coraz częściej się profesjonalizują i przenoszą do internetu. Wynika to z kilku czynników. Po pierwsze, rynek oferuje ogromne możliwości dokształcania się w coraz większej liczbie dziedzin, przy czym część oferty dostępna jest również on line ${ }^{6}, \mathrm{z}$ czego $\mathrm{w}$ dużej mierze zapewne korzysta młodzież. Po drugie, dzięki internetowi znacznie łatwiej dzielić się posiadaną wiedzą - bez problemu można znaleźć grupy internetowe, gdzie osoby zainteresowane podobnymi zagadnieniami mogą wymieniać się doświadczeniami, nie brakuje blogów i kanałów YouTube na niemal każdy temat. I wreszcie po trzecie, handel internetowy sprawił, że amatorzy mają ułatwiony dostęp do profesjonalnego sprzętu. Często jedyną przeszkodą w zakupie jest cena, która jednak spada ze względu na wzmożony popyt (takie zjawisko dotyczy między innymi sprzętu fotograficznego i elektronicznego).

Także te obszary spędzania czasu wolnego, które nie wymagają żadnych umiejętności, stają się polem interesujących przemian. Interaktywne media oraz możliwość łatwego tworzenia własnych treści w internecie (Jenkins 2007) sprawiły, że ich odbiorca przestał być bierny. Dziś może on nie tylko wybierać, gdzie i w jaki sposób ma kontakt $z$ kulturą popularną czy rozrywką, ale również do pewnego stopnia decydować o jej formie, wywierając nacisk czy to za pomocą wpisów na portalach społecznościowych, petycji czy podpisywanych w internecie (Earl, Schussman 2008). Może sam tworzyć nowe treści, opierając się na tych już istniejących, na przykład przez pisanie fan fiction (opowiadań rozgrywających się w stworzonym przez kogoś innego świecie), rysowanie fan artów (grafiki przedstawiającej ulubionych bohaterów), tworzenie memów, blogów czy kanałów YouTube z recenzjami, interpretacjami czy krytyką.

Dostęp do mediów społecznościowych ma coraz większa liczba osób. W Polsce jest to około $50 \%$ populacji ${ }^{7}$. Jednak nie każdy użytkownik jest jednocześnie kreatorem treści. Badacze internetu szacują, że liczba twórców jest w rzeczywistości bardzo niska, od kilku do kilkunastu procent.

${ }^{6}$ Według danych GUS (2016) w Polsce kształciło się 45,1\% osób w wieku 18-69 lat, w tym $30,7 \%$ w edukacji nieformalnej.

7 Digital in 2020, Hootsuite (https://wearesocial.com/digital-2020 [dostęp: 10.09.2020]). 
Można wyróżnić typ internautów bardzo aktywnych (jeden do kilku procent użytkowników), takich, którzy tworzą treści sporadycznie (szacuje się, że stanowią oni od kilkunastu do niemal połowy użytkowników), i resztę, wyłącznie konsumującą treści (tak zwanych podglądaczy, od angielskiego słowa lurker, oznaczającego osobę śledzącą forum dyskusyjne, ale nie udzielającą się w wymianie zdań) (Nielsen 2006; van Mierlo 2014). Proporcje te rozkładają się różnie w różnych grupach społecznych (Brandtzaeg, Heim 2011). Badacze (Hargittai, Walejko 2008) zwracają uwagę, że stopień aktywności w sieci może zależneć od płci lub statusu majątkowego użytkownika). Mimo zaobserwowanych zróżnicowań nie ulega wątpliwości, że nowe technologie umożliwiły powstanie odmiennych sposobów spędzania wolnego czasu.

Opisane zjawiska dotyczą także czasu wolnego najmłodszych, a zwłaszcza nastolatków. Oni również tworzą fanowskie opowiadania, prowadzą blogi i kanały na YouTube, produkują biżuterię, intensywnie trenują sport, uczą się języków i podejmują wiele zajęć, które mają w przyszłości zwiększyć ich szanse na dobrą pracę. Młodzi ludzie stają się w internecie zarówno konsumentami, jak i wytwórcami treści (Lenhart, Madden 2005) - kanał na YouTubie czy konto na Instagramie może prowadzić legalnie każdy powyżej trzynastego roku życia. Według danych z 2017 roku, $4,7 \%$ polskiej młodzieży ma własny blog lub stronę internetową, około $5 \%$ podejmuje próby skomponowania własnej muzyki lub stworzenia filmu. Nieco więcej, bo około $8 \%$ nastolatków w wolnym czasie zajmuje się robieniem i edycją zdjęć (Tanaś i in. 2017). Istotne jest, że zarówno portale społecznościowe, jak i wiele gier komputerowych czy aplikacji na smartfony daje możliwość generowania zysków. Niektórzy badacze (Goggin 2018) mówią nawet o wyłanianiu się nowego zjawiska zwanego playbour (od połączenia słów: play - gra, zabawa, labour — praca), które polega na mieszaniu się dwóch kategorii zajęć, dotychczas stawianych w opozycji. Młodzi ludzie, grając w gry lub prowadząc działalność w mediach społecznościowych, nie tylko wydają, ale i zarabiają pieniądze, niejednokrotnie wikłając się w działalność hazardową (Zendle, Meyer, Over 2019). Jest to zagadnienie ciekawe zarówno z socjologicznego, jak i ekonomicznego czy prawnego punktu widzenia, ponieważ działalność ta należy do szarej strefy, a jednak jest dość powszechna.

Rozwój nowych technologii oraz zmiany na rynku pracy sprawiły zatem, że w wielu przypadkach niemożliwe stało się wyraźne oddzielenie czasu pracy od czasu wolnego. Jednocześnie wiele zajęć podejmowanych dotychczas w czasie wolnym wyłącznie dla rozrywki stało się okazją do nabycia nowych umiejętności lub rozwoju zawodowego. Nawet tradycyj- 
nie postrzegane obszary bierności, odpoczynku czy konsumpcji stają się dzisiaj pożywką dla działań twórczych. Nastolatki uczestniczą w tym procesie na wielu poziomach — angażując się aktywnie w hobby wymagające różnych umiejętności, podejmują aktywność twórczą czy zarabiają w internecie.

\section{SPĘDZANIE CZASU WOLNEGO \\ JAKO WYZNACZNIK POZYCJI W HIERARCHII SPOŁECZNEJ}

Dla wielu badaczy, jak wspominałam, czas wolny tradycyjnie stanowił jedynie dopełnienie czasu pracy. Ten drugi, a nie pierwszy element świadczył o pozycji zajmowanej przez jednostkę w społeczeństwie. Na istotność czasu wolnego jako wyznacznika pozycji społecznej pierwszy zwrócił uwagę Thorstein Veblen, opisując w Teorii klasy próżniaczej (1998) czas wolny jako wyznacznik prestiżu. Jako czas wolny definiował wszystko, co nie było pracą produkcyjną, której wykonywanie $\mathrm{w}$ wówczesnych czasach uznawano jednak za mało prestiżowe. Istotne były nie pieniądze, lecz możliwość oddawania się specyficznym zajęciom, co Veblen określał mianem próżnowania. W świetle tej teorii czas wolny jest zatem jednym $z$ najważniejszych zasobów - człowiek majętny posługiwał się nim, by poprzez ostentacyjną konsumpcję zaznaczyć swoją pozycję i uzyskać pożądany prestiż. Czas wolny jako ścisły wyznacznik prestiżu to jednocześnie rodzaj pracy - próżnowanie wymagało wysiłku, nie tylko finansowego, ale również fizycznego i emocjonalnego, było obowiązkiem, od którego nie można się było uchylać, jeśli chciało się utrzymać pozycję w hierarchii społecznej.

Niezwykle istotny w teorii Veblena jest element performatywny. Pozycję społeczną potwierdza się na rozmaite sposoby - uprawiając sport, bywając w odpowiednich miejscach czy zakładając właściwe stroje. Kontynuacją i rozwinięciem tej koncepcji stał dramaturgiczny model relacji społecznych Ervinga Goffmana. Nie zajmował się on bezpośrednio tematyką czasu wolnego, zwracał jednak uwagę na elementy niezbędne do właściwego odegrania roli, która odppowiada pozycji zajmowanej przez jednostkę w społeczeństwie. Powinno się mieć dpowiednią powierzchowność (appearance) i sposób bycia (manner). Goffman (1981, s. 57) pisze: „Kiedy aktor przyjmuje określoną rolę społeczną, zdaje sobie zazwyczaj sprawę, że przypisana jest już do niej określona fasada”. Prezentowanie fałszywej fasady wiąże się $z$ niejasnym statusem i niesie ryzyko bycia rozpoznanym jako fałszerz. Aby uniknąć takiego upokorzenia, przedstawiciele poszczególnych klas powinni sumiennie odgrywać swoje role we wszelkich sytuacjach publicznych. Elementy przedstawienia mają znacze- 
nie symboliczne - odgrywający swoją rolę aktor wybiera je świadomie, aby jak najlepiej wypaść w swojej roli. W myśl teorii Goffmana, podobnie jak u Veblena, przestrzeganie zasad rządzących przedstawieniem czy ostentacyjnym próżnowaniem wymaga wiedzy, wysiłku i praktyki.

Podobnie postrzega hierarchię społeczną Pierre Bourdieu (2005; Bourdieu, Passeron 2012) nie mamy tu jednak do czynienia z przedstawieniem odgrywanym przez świadomego swej roli aktora. Hierarchia społeczna, według niego, ma również charakter performatywny, a zatem liczy się to, czym przedstawiciele poszczególnych klas się zajmują, w co się ubierają i dokąd chodzą, ale tym, co odróżnia od siebie poszczególne klasy, jest gust, różny na poszczególnych szczeblach drabiny społecznej. W opinii przedstawicieli klasy średniej „gust” jest czymś wrodzonym, naturalnym i oczywistym, Bourdieu dowodzi jednak, że to, co uznajemy za „gustowne”, nie jest estetyczne ani zachwycające samo w sobie, lecz postrzegają to jako takie osoby o specyficznym kapitale kulturowym, nabywanym $\mathrm{w}$ toku edukacji, formalnej i nieformalnej, otrzymywanej w domu rodzinnym. U Veblena decydującym kryterium przynależności do klasy wyższej była wysoka wartość materialna posiadanych przedmiotów oraz brak praktycznego aspektu podejmowanych zajęć. Bourdieu dodaje kryterium piękna - klasy wyższe cenią sobie to, co estetyczne, a za takie może zostać uznane tylko to, co trudne w odbiorze, wymagające wykorzystania nabytych wcześniej kompetencji, nieoczywiste. Ma to bezpośrednie przełożenie na sposoby spędzania czasu wolnego przez przedstawicieli poszczególnych klas. Zgodnie z teorią Bourdieu, osoby posiadające wyższy kapitał kulturowy, społeczny i ekonomiczny mogą wybierać, w jaki sposób chcą spędzić wolny czas i na co wydać pieniądze, podczas gdy przedstawiciele klasy robotniczej skazani są na to, na co mogą sobie pozwolić przy ograniczonych budżetach i typie wykonywanej pracy („konieczność techniczna”; Bourdieu 2005, s. 466).

$\mathrm{Na}$ polskim gruncie czas wolny jako element przedstawienia świadczącego o statusie czy pozycji społecznej opisywało wielu badaczy. Henryk Domański w rozprawie dotyczącej prestiżu wskazuje na powiązanie prestiżu z zajęciami czasu wolnego: „O identyfikacji nie decydują już tylko rodzina, pozycja zawodowa i miejsce pracy, ale preferencje dotyczące konsumpcji i wypoczynku" (Domański 1999, s. 77). Z kolei w monografii Wzory jedzenia (Domański i in. 2015) autorzy wiążą dystanse między kategoriami społecznymi z rodzajem posiłków i sposobami ich spożywania, bezpośrednio odwołując się do teorii Bourdieu, a na przykład Tomasz Zarycki (2008) sięga do teorii Bourdieu w badaniach poświęconych inteligencji polskiej i rosyjskiej, wskazując na związki między pochodzeniem studentów a kształtowaniem się gustów artystycznych. 
Zastanawiając się nad użytecznością wyżej opisanych teorii w badaniach czasu wolnego, należy zauważyć problematyczny element — niebranie pod uwagę wewnętrznego zróżnicowania opisywanych klas. Wyraźne trendy w sposobach spędzania czasu wolnego przedstawicieli poszczególnych klas społecznych zapewne istnieją, ale rozrywki dziecięce i rozrywki osób starszych różnią się od siebie tak bardzo, że być może bardziej zasadne byłoby postawienie znaku równości między dziećmi z różnych klas niż dziećmi i dorosłymi zajmującymi tę samą pozycję na drabinie społecznej. Na czas wolny nastolatków należy patrzeć szerzej, biorąc pod uwagę również inne uwarunkowania, aby w pełni zrozumieć specyfikę sytuacji tej grupy wiekowej. Jest to istotne zwłaszcza w dobie gwałtownego rozwoju technologii cyfrowych, który wprowadza nowe podziały w społeczeństwie. Tworzące się za pośrednictwem internetu międzynarodowe wspólnoty, mające charakter opisywanych przez Michela Maffesolego (2008) plemion, stają się istotnym punktem odniesienia dla młodych ludzi. Ma to przełożenie na wybór ścieżki zawodowej, rozwój umiejętności czy kształtowanie gustów. Młodzi ludzie nabywają w sieci kompetencje, których brakuje wielu osobom dorosłym, co może mieć wpływ na zajmowaną przez nich pozycję w hierarchii społecznej.

\section{STYL ŻYCIA JAKO ELEMENT TOŻSAMOŚCI}

Tam gdzie Veblen, Bourdieu czy Weber szukają motywacji wyborów związanych z czasem wolnym w schemacie klasowym, inni badacze starają się powiązać go z bardziej subiektywnymi kategoriami — wartości, potrzeb i preferencji (Marody 1997). Kategoria stylu życia w pewnym sensie łączy te dwa podejścia, pozwalając przyjrzeć się zarówno miejscu jednostki w społeczeństwie, jak i czynnikom indywidualnym, które składają się na jej preferencje. W teorii Webera style życia miały charakter wspólnotowy i stanowiły wyznacznik statusu społecznego, dla Veblena pozostawały ściśle powiązane $z$ wzorami konsumpcji, Bourdieu zaś przedstawił koncepcję habitusu jako elementu łączącego pozycję społeczną jednostki z jej indywidualnymi wyborami. Style życia oczywiście są powiązane z sytuacją klasową, ale pojęcie to jest również użyteczne w opisie kategorii, które funkcjonują niejako w poprzek podziałów ekonomicznych, a którym wyżej wymienieni badacze nie poświęcali szczególnej uwagi. Można w ten sposób opisać chociażby subkultury, mniejszości etniczne czy seksualne. Kategoria ta wiąże się z pojęciem społeczeństwa nowoczesnego — styl życia pojawia się tam, gdzie istnieje możliwość wyboru.

„W warunkach późnej nowoczesności - pisze Anthony Giddens (2002, s. 113) — każdy ma jakiś styl życia, i w dodatku jest do tego w istot- 
nym sensie zmuszony: nie ma wyboru — trzeba wybierać. Styl życia można zdefiniować jako mniej lub bardziej zintegrowany zespół praktyk, które podejmuje jednostka nie tylko dlatego, że są użyteczne, ale także dlatego, że nadają materialny kształt poszczególnym narracjom tożsamościowym". Styl życia w takim ujęciu to projekt, w którym jednostka musi wziąć udział świadomie, aby we właściwy sposób wykreować swoje ,ja” i pokazać przynależność do wybranej przez siebie klasy, grupy czy wspólnoty. W świetle takiego podejścia zajęcia czasu wolnego stają się więc elementem pracy nad tożsamością.

Choć, jak słusznie zauważa Giddens, styl życia w wielu wypadkach polega na dokonywaniu określonych wyborów konsumpcyjnych, wysiłek włożony w urefleksyjnienie własnej pozycji w społeczeństwie może przekładać się też na postawy antymaterialistyczne. Zajęcia takie jak samokształcenie, rozwijanie hobby, a także działania proekologiczne, na przykład własnoręczne szycie ubrań (zajmujące znacznie więcej czasu niż zwykłe zakupy), mieszczące się w szerokiej definicji czasu wolnego (uwzględniającej serious leisure), stają się elementami określającymi tożsamość jednostki. Jest to aspekt niezwykle ważny zwłaszcza z punktu widzenia badań młodzieży, która w wieku kilkunastu lat zadaje sobie pytanie „kim chcę być?”, a dokonywane przez nią wybory po raz pierwszy stają się elementem tworzonej świadomie tożsamości. Dobór takich lub innych zajęć pozalekcyjnych, zaangażowanie $\mathrm{w}$ działalność wolontariacką, poświęcenie się nauce lub sportowi, próby stworzenia własnego kanału czy profilu w mediach społecznościowych - wszystkie te zajęcia stają się częścią projektu „ja”. Jak pokazują autorzy raportu Młodzi $i$ media, pojawienie się nowych mediów sprawiło, że należy inaczej patrzeć na kwestię uczestnictwa młodych ludzi w kulturze. Przenosi się ono do sieci i nabiera nieformalnego charakteru. Redefiniowane są także wytwory kultury - są adaptowane i przerabiane zgodnie z potrzebami młodych ludzi. Problemem staje się nie dostęp do wytworów kultury, lecz raczej wybranie $z$ wielu możliwości propozycji dla siebie (Filiciak i in., 2010). Jacek Pyżalski (2016) zauważa, że $\mathrm{w}$ działalności młodych ludzi nie należy rozdzielać formy online i offline, ponieważ często przybiera ona podobną postać, jest specyficznym środowiskiem działania młodych ludzi i miejscem kreowania przez nich swojej tożsamości. Autor wskazuje, że młodzi ludzie, którzy aktywnie angażowali się w działalność w internecie, byli aktywni również aktywnie w tzw. realu, na przykład gracze komputerowi częściej spotykali się przy tradycyjnych grach, blogerzy prowadzili pamiętniki i częściej brali udział w zajęciach dodatkowych, a wolontariusze internetowi angażowali się $\mathrm{w}$ działalność podobnego typu poza siecią. Nie należy zatem postrzegać internetu jako 
zagrożenia dla kreowania siebie, lecz jako odbicie realnego świata podlegające podobnym procesom.

Możemy w związku z tym założyć, że pewne aspekty „ja” jednostki będą realizować się wyłącznie w czasie wolnym od szkoły czy pracy oraz że wzorce kulturowe czerpane nie $z$ bezpośredniego doświadczenia, lecz przekazu medialnego wpłyną na wybory jednostki związane $z$ relacjami społecznymi czy rodzinnymi i będą przekładać się na preferowane style życia. Na przykład obecność w kulturze osób otwarcie homoseksualnych może wpływać nie tylko na wybory w zakresie muzyki popularnej czy seriali telewizyjnych, ale również na poczucie identyfikacji z daną mniejszością seksualną (Kivel, Kleiber 2000) czy poczucie własnej wartości.

Czas wolny jako przestrzeń kreowania tożsamości rozpatrują także teorie feministyczne. W Leisure and Feminist Theory Betsy Wearing (1998) zwraca uwagę na fizyczne aspekty przestrzeni miejskiej, która - zaprojektowana przez i dla meżczyzn - spycha kobiety i dzieci w najlepszym razie na przedmieścia, nie biorąc pod uwagę ich specyficznych potrzeb. Badaczka proponuje więc przedefiniować czas wolny (lesuire) jako prywatną przestrzeń, w której kobiety mogą tworzyć i odgrywać swoje „ja”, eksplorować pragnienia i przyjemności. Może to być przestrzeń fizyczna lub metaforyczna, ale powinna dawać kobiecie poczucie bezpieczeństwa, dzięki któremu może ona odkrywać, kim naprawdę jest, w sposób performatywny, a nie narzucony przez społeczne wyobrażenia własnej płci. A zatem Wearing proponuje, aby czas wolny stał się przestrzenią pozwalająca na bezpieczne eksperymentowanie z tożsamością. Dla nastolatków taką przestrzenią może stać się internet. Ciekawym przykładem „bezpiecznego miejsca" odgrywania różnych scenariuszy dotyczących własnej tożsamości mogą być opisane przez Catherine Tosenberger (2008) portale do tworzenia i umieszczania fan fiction (opowiadań fanowskich rozgrywających się w świecie wykreowanym przez ulubionego twórcę). Przytacza ona przykład dziewcząt i młodych kobiet, które w swojej twórczości opisują niemal wyłącznie relacje męsko-męskie (tak zwany slash), o różnym stopniu intensywności, często bardzo erotyczne. Zdaniem badaczki, taka twórczość pozwala na bezpieczne projektowanie własnej seksualności oraz eksperymentowanie $z$ potrzebami na tym polu. Erotyczne opisy, w przeciwieństwie do seksu uprawianego w realnym świecie, nie stanowią zagrożenia dla bezpieczeństwa nastolatek, a połączenie w pary bohaterów tej samej płci pozwala na zneutralizowanie relacji władzy w związku (Tosenberger, 2008, s. 189). Pisanie staje się więc narzędziem samopoznania.

Kolejnym narzędziem w badaniu powiązań pomiędzy czasem wolnym a tożsamością może stać się teoria intersekcjonalności (Crenshaw 1989), 
zwana również w Polsce teorią przecięć lub dyskryminacji wielokrotnej. Zaproponowana została ona przez amerykańskie czarnoskóre feministki, które zwracały uwagę na fakt, że doświadczenia białych kobiet różnią się od doświadczeń kobiet pochodzących z mniejszości. Z jej pomocą można wskazać, w jaki sposób różne aspekty pozycji społecznej nakładają się na siebie i przyczyniają do dyskryminacji lub pozwalają jej uniknąć. W badaniach nad czasem wolnym teoria ta pozwala lepiej opisać nie tylko doświadczenia kobiet, przedstawicieli mniejszości etnicznych czy seksualnych. Wydaje się, że użycie jej w badaniach czasu wolnego młodzieży mogłoby pomóc uwypuklić pewne zjawiska. Przykładem takiego obszaru może stać się chociażby badanie przestrzeni miejskiej, w której młodzi ludzie codziennie funkcjonują, a która rzadko tworzona jest zgodnie $z$ ich potrzebami. Idealizowanie dzieciństwa sprawia, że za naturalne środowisko dziecka uważa się raczej wieś niż miasto (Wells 2002, 2005). Środowiska miejskie traktuje się jako potencjalnie niebezpieczne, pomimo że w miastach na świecie mieszka około miliarda dzieci (Unicef 2012) i liczba ta stale rośnie. $Z$ prowadzonych przeze mnie badań wynika, że urzędnicy traktują młodzież stereotypowo lub zupełnie ją ignorują, w przekonaniu, że nastolatki są ,trudne”, skupione na sobie i nieskłonne do współpracy (Żbikowska 2019). Jednocześnie zapominają o tym, że nastolatki to grupa zróżnicowana płciowo, wyznaniowo oraz pod względem statusu społecznego.

Style życia w rozumieniu Giddensa mogą zatem stać się przestrzenią kreowania własnej tożsamości, a czas wolny — przestrzenią, w której wypróbowywane są różne życiowe scenariusze. Zapewne zatem wybory związane $z$ czasem wolnym $w$ poszczególnych grupach społecznych będą uławiały lub utrudniały osobom niepełnoletnim realizowanie projektu „ja”. W sytuacji, gdy pewne elementy tożsamości nie mogą być zrealizowane $\mathrm{w}$ sposób otwarty, czy to $\mathrm{z}$ powodu presji ze strony rodziców, czy rówieśników, młodzi ludzie mogą starać się realizować je w przestrzeni świata wirtualnego lub oddawać się wybranym zajęciom w ukryciu, w tajemnicy przed bliskimi osobami. W tym kontekście niezwykle istotne wydaje się, aby mieli oni do dyspozycji czas, w którym mogą swobodnie dobierać zajęcia w sposób pozwalający im realizować indywidualne potrzeby. Wszystkie te aspekty każą nam się zastanowić, które elementy czasu wolnego młodzi ludzie wybierają do tworzenia własnej tożsamości i na ile czas wolny stanowi dla nich przestrzeń eksperymentowania $z$ tożsamością, a na ile realizują w nim style życia zgodne $z$ oczekiwaniami rodziców, rówieśników lub społeczeństwa.

W polskiej socjologii pojęcie stylu życia wyraźnie zaistniało w latach siedemdziesiątych XX wieku za sprawą badań prowadzonych przez An- 
drzeja Sicińskiego i jego zespół, a także przez Andrzeja Tyszkę (1971). Siciński (1976 s. 16) sformułował następującą definicję: „Styl życia w naszym rozumieniu jest więc określeniem relatywnym: istotne są tu bowiem te rodzaje zachowań, które - bądź w intencji osób zachowujących się, bądź przez obserwatora - uznawane są za takie, po których można "poznać» kogoś, to znaczy zdefiniować go, zlokalizować społecznie”. W takim ujęciu zatem styl życia komunikuje pewne informacje na temat jednostki i jest ściśle związany z pozycją społeczną. Kategoria ta okazała się niezwykle istotna $\mathrm{w}$ polskich badaniach socjologicznych $\mathrm{w}$ okresie przejścia od ustroju komunistycznego do kapitalizmu, kiedy struktura klas i wyznaczniki pozycji społecznej ulegały gwałtownym przeobrażeniom.

\section{CZAS WOLNY JAKO ZABAWA}

Dotychczas skupiałam się na tym, w jaki sposób dobór zajęć czasu wolnego przekłada się na sytuację zawodową jednostki oraz jej pozycję w hierarchii społecznej. Teraz kieruję uwagę na podejścia teoretyczne umożliwiające uchwycenie istoty „czasu wolnego” jako momentu przyjemności i relaksu (Szafraniec, Boni 2011). W takim ujęciu czas wolny to nie określony moment dnia czy tygodnia, ale stan umysłu. To czas wolności i swobody - który podobnie jak zabawa w definicji Johana Huizingi (1998) — jest celem samym w sobie. Poddajemy mu się dobrowolnie i oczekujemy go z radością. Rozrywka jako taka rzadziej jest podejmowana jako temat badawczy, choć stanowi ona znaczącą pozycję w budżecie czasu dzieci i młodych ludzi. Przywoływany już Roger Stebbins (2007) do kategorii „swobodny czas wolny” zaliczał wszystkie czynności dające przyjemność natychmiastową, lecz względnie krótkotrwałą, i nie wymagające specjalnych kompetencji, takie jak oglądanie telewizji, słuchanie muzyki, amatorski sport czy jedzenie. Takie podejście nie oddaje jednak złożoności zjawiska, jakim jest rozrywka, nie mówi nic o jej funkcji czy społecznych uwarunkowaniach. Inne częste podejście do kwestii czasu wolnego polega na interpretowaniu go jako uczestnictwa w kulturze. Badania w tym zakresię są prowadzone $\mathrm{w}$ Polsce od lat na bardzo wielu poziomach i w wielu obszarach, wystarczy chociażby wspomnieć coroczne badania czytelnictwa prowadzone przez Bibliotekę Narodową, badanie „Kultura małych i średnich miast" (Sztark 2016) czy dotyczące młodzieży badania Barbary Fatygi (2001). Ograniczenie pojęcia „rozrywka” do uczestnictwa w kulturze powoduje jednak, że wiele aspektów czasu wolnego młodzieży wymyka się badaniom lub może zostać błędnie zinterpretowanych. Weźmy pod uwagę chociażby badania czytelnictwa - zgodnie z nimi, dzieci i młodzież 
stanowią grupę czytającą najwięcej ze wszystkich grup wiekowych $(54 \%$ mężczyzn w wieku 15-24 lata przeczytało w ubiegłym roku przynajmniej jedną książkę w porównaniu do $34 \%$ czytających mężczyzn ogółem, wśród kobiet odsetek ten wyniósł $65 \%$ do 47\% (Biblioteka Narodowa 2018). Oczywiście wynik ten w dużej mierze wymuszany jest przez konieczność czytania lektur szkolnych. Podobnie sprawa ma się z wyprawami do teatru czy kina. Nastolatki rzadko dysponują własnymi pieniędzmi, a jeśli już je zarabiają, raczej nie wydają ich na wyjścia kulturalne. Do ośrodków kultury wybierają się z rodzicami albo ze szkołą. Otwarte zatem pozostaje pytanie, jaką rolę $w$ ich życiu pełnią zajęcia czasy wolnego, czy faktycznie czerpią z nich jakąkolwiek przyjemność czy korzyść, czy też raczej jest to dla nich nudny obowiązek.

Skoro stopień uczestnictwa $\mathrm{w}$ kulturze $\mathrm{w}$ przypadku młodzieży nie przekłada się bezpośrednio na przyjemność czerpaną z zajęć czasu wolnego, być może należy posłużyć się innym sposobem badania tego zagadnienia. Koncepcja „zabawy” może pomóc zdefiniować zajęcia służące rozrywce i relaksowi i przyjrzeć się temu, co indywidualne w czasie wolnym. Jak zauważa James Combs (2011), zabawa jest czymś, co wszyscy są w stanie rozpoznać, choć bardzo trudno ją opisać. Wiąże się z poczuciem przyjemności i zatracenia $\mathrm{w}$ doświadczeniu, niezależnie od tego, czy jest to doświadczenie osobiste (np. euforia, jakiej doświadczamy w tańcu) czy zapośredniczone (kibicowanie ulubionej drużynie piłkarskiej w trakcie ważnego meczu). Według Huizingi (1998, s. 22): „zabawa jest dobrowolną czynnością lub zajęciem wykonywanym w pewnych ustalonych granicach czasu i przestrzeni według dobrowolnie przyjętych, lecz bezwarunkowo obowiązujących reguł, jest celem sama w sobie, towarzyszy jej zaś uczucie napięcia i radości oraz świadomość «odmienności» od "zwyczajnego życia»". Ten histororyk i kulturoznawca interpretuje zabawę jako zjawisko wyraźnie pozytywne, co nasuwa refleksję o etycznych aspektach czasu wolnego. Dark leisure, czyli spędzanie czasu wolnego na zajęciach nieakceptowanych społecznie, niebezpiecznych lub wręcz patologicznych, rzadko staje się elementem stylu życia lub wyznacznikiem prestiżu (choć oczywiście to, co uważamy za patologiczne, może znacząco różnić się w zależności od okresu historycznego, grupy społecznej czy norm kulturowych). Aby można było opisać ten aspekt czasu wolnego, potrzebne jest pojęcie, które pomoże uchwycić samą istotę zabawy, bez nadawania jej wymiaru etycznego. Część badaczy, zwłaszcza z dziedziny psychologii, traktuje czas wolny jako stan umysłu. John Neulinger (1970) proponował definicję, zgodnie z którą czas wolny wyznacza przede wszystkim poczucie wolności wyboru. Jak już wspomniałam wcześniej, „wolność” w doborze zajęć czasu 
wolnego może być w dużej mierze pozorna, zwłaszcza jeśli chodzi o dzieci i młodzież, i taki też zarzut postawiono definicji Neulingera. W późniejszych pracach autor częściowo zmodyfikował swoją definicję, zaznaczając, że choć poczucie wolności może być iluzoryczne, istotne jest wrażenie jednostki, że jej czas należy do niej i może $z$ nim zrobić, co zechce.

Inne podejście zastosował Mihaly Csikszentmihalyi (1996) Zgodnie $z$ jego teorią, kluczowe dla poczucia zadowolenia jednostki jest osiągnięcie stanu nazywanego flow - przepływem. Jest to moment, w którym poziom naszych umiejętności i poziom trudności wyzwania, przed jakim stajemy, są sobie równoważne. Dzięki temu wykonywane zadanie nie nudzi nas, ale także nie męczy. Możemy doświadczyć wielu pozytywnych wrażeń, takich jak odprężenie, wolność od lęku przed porażką, brak problemów ze skupieniem się, poczucie panowania nad sytuacją, brak świadomości upływającego czasu - a więc zatracamy się w danej czynności. Takiego stanu możemy doświadczyć dzięki niektórym zajęciom czasu wolnego - medytując lub uprawiając jogę, biegnąc, grając $w$ grę. Teoria Csikszentmihalyiego pozwala również uniknąć moralnej oceny podejmowanej czynności równie dobrze flow można osiągnąć, włamując się do opuszczonych budynków, pijąc alkohol czy wdając się w kibicowską bójkę.

Takie podejście jest przydatne, ponieważ czas wolny dzieci i nastolatków podlega negocjacjom w obrębie rodzin, a oczekiwania co do wyboru zajęć bywają tyleż określone, co sprzeczne. Nastolatki, zwłaszcza młodsze, wciąż mają, podobnie jak dzieci, dużą potrzebę zabawy, ale przyzwolenie na nią ze strony dorosłych $w$ ich wypadku jest już zdecydowanie mniejsze (w odczuciu społeczeństwa powinni podjąć inne, poważniejsze zajęciami, które w przyszłości zaprocentują lepszą pracą i wyższymi zarobkami). Jednocześnie próby podjęcia zachowań „dorosłych”, takich jak picie alkoholu czy seks, budzą przerażenie rodziców i opiekunów, którzy boją się nie tylko o zdrowie i dobrostan swoich podopiecznych, ale również o konsekwencje tych zachowań w przyszłości. Bycie „zbyt dziecinnym” jest zatem potępiane na równi z byciem „zbyt dorosłym” - i w konsekwencji zdarza się, że potrzeby odpoczynku i relaksu młodych ludzi pozostają niezaspokojone.

\section{PODSUMOWANIE}

Nastolatki to grupa wiekowa postrzegana niejednoznacznie, zarówno przez badaczy, jak i przez ogół społeczeństwa - media, pracowników różnych instytucji, rodziców. Przyczyn ambiwalencji jest wiele, począwszy od typowego konfliktu pokoleń, poprzez zachodzące w młodych ludziach zmiany związane $z$ ciałem (sprawiające, że ich zachowania postrzegane są jako 
irracjonalne), po stan prawny, zgodnie z którym wciąż są dziećmi i powinni podlegać ochronie, choć ich wygląd i zachowanie wskazują na dojrzałość. Do tego dochodzi język - szybko ewoluujący slang, który daje młodym ludziom poczucie przynależności do własnej grupy (Farajado 2019), jednocześnie wykluczając z niej osoby starsze. W efekcie młodzież postrzegana jest stereotypowo — jako „odrębny gatunek”. Barbara Fatyga (2005) mówi wręcz o „dzikusach" - niby swoich, ale jednak obcych członkach społeczeństwa. Stereotyp nastolatka zakłada jego buntowniczość, skłonność do ryzykownych zachowań i zmienność nastrojów (Gross, Hardin 2007), a zestaw charakteryzujących go cech traktowany jest jako uniwersalny.

Doświadczenie dorastania postrzegane jest jako ujednolicające, tymczasem nie jest prawdą, że nastolatki stanowią jednolitą grupę o identycznej kulturze na terenie całych miast czy nawet krajów. To grupa zróżnicowana wewnętrznie pod względem własnych kultur, stylów życia i wzorów konsumpcji. Jej członkowie są konsumentami produktów, które rzadko sami wytwarzają (choć zmienia się to za sprawą internetu). Strzeże się ich przed konsekwencjami własnych czynów, jednocześnie pozbawiając praw obywatelskich (wykluczenie $z$ debat społecznych, brak prawa do głosowania) i kontrolując (kamery w szkołach, „godziny policyjne” w miastach dla dzieci poniżej określonego wieku, patrole szukające wagarowiczów). Uznaje się ich za wystarczająco dojrzałych, by podejmowali decyzje finansowe, ale nie dość dorosłych, by mogli podjąć pracę zarobkową (z wyjątkiem zajęć dorywczych, na które potrzebują zgody rodziców). Status grupy „pomiędzy” dzieciństwem a dorosłością staje się zatem jednocześnie przekleństwem i błogosławieństwem, zapewniając swobodę w jednych obszarach i nakładając ograniczenia $w$ innych. Również tworzone przez media ogólne obrazy „danego pokolenia” sprawiają, że choć młodzi ludzie postrzegają siebie jako grupę społeczną, mają niskie poczucie sprawczości i rzadko podejmują działania mające na celu poprawę swojej sytuacji.

W efekcie ich potrzeby pozostają nierozpoznane, brakuje im również narzędzi, które pozwoliłyby wziąć udział $\mathrm{w}$ rozmowie na własny temat na forum publicznym. Często nie mają świadomości, że ich głos mógłby stać się cennym wkładem $\mathrm{w}$ dyskusję na temat kształtowania otaczającej rzeczywistości. Wydaje się zatem, że przyjrzenie się różnym obszarom życia nastolatków może dać ważne odpowiedzi na pytanie o to, jak włączać młodych ludzi do debaty publicznej.

Przegląd teorii czasu wolnego ujawnia bardzo wiele wątków, które warto byłoby poruszyć w przyszłych badaniach nastolatków. Zwłaszcza interesujące wydają się aspekty dotychczas w tym kontekście nie badane. Na przykład zjawiska na styku rozrywki i pracy (szara strefa zarobków w sie- 
ci), elementy negatywnego czasu wolnego (dark leisure) inne niż używki czy młodzieżowa twórczość (zarówno internetowa, jak i rękodzieło). Wydaje się, że teorie ujmujące funkcje czasu wolnego w odniesieniu do całego społeczeństwa w badaniach nastolatków mają ograniczone zastosowanie. Lepiej sprawdziłyby się zapewne teorie skupione na aspektach budowania tożsamości lub te, które pozwalają uchwycić radość z wykonywanych czynności, jednocześnie unikając ich moralnej oceny.

\section{BIBLIOGRAFIA}

Barber Larissa, Santuzzi Alecia, 2017, Telepressure and College Student Employment: The Costs of Staying Connected Across Social Contexts, „Stress and Health”, t. 33, s. 14-23 (https:// doi.org/10.1002/smi.2668).

Belkin Liuba, Becker William, Conroy Samantha, 2020, The Invisible Leash: The Impact of Organizational Expectations for Email Monitoring After-Hours on Employee Resources, Well-Being, and Turnover Intentions, „Group and Organization Management”, t. 0(0), s. 1-32 (DOI: $10.1177 / 1059601120933143)$.

Biblioteka Narodowa, 2018, Stan czytelnictwa w Polsce w 2017 roku, Biblioteka Narodowa, Warszawa.

Brandtzaeg Petter, Heim Jan, 2011, A Typology of Social Networking Sites Users, „International Journal of Web Based Communities", t. 7(1), s. 28-51 (DOI: 10.1504/IJWBC.2011.0381 24).

Bourdieu Pierre, 2005, Dystynkcja. Społeczna krytyka władzy sądzenia, tłum. Piotr Biłos, Scholar, Warszawa.

Bourdieu Pierre, Passeron Jean-Claude, 2012, Reprodukcja. Elementy teorii systemu nauczania, tłum. Elżbieta Neyman, Wydawnictwo Naukowe PWN, Warszawa.

Clarke John, Critcher Chas, 1985, The Devil Makes Work: Leisure in Capitalist Britain, University of Illinois Press, Champaign.

Combs James, 2011, Świat zabaw: narodziny nowego wieku ludycznego, tłum. Olga Kaczmarek, Wydawnictwa Uniwersytetu Warszawskiego, Warszawa.

Cook Daniel Thomas, 2004, The Commodification of Childhood: The Children's Clothing Industry and the Rise of the Child Consumer, Duke University Press, Durham.

Cook Daniel Thomas, 2007, The Disempowering Empowerment of Children's Consumer, „Society and Business Review", t. 2(1), s. 37-52.

Crenshaw Kimberle, 1989, Demarginalizing the Intersection of Race and Sex: A Black Feminist Critique of Antidiscrimination Doctrine, Feminist Theory and Antiracist Politics, „University of Chicago Legal Forum", t. 1989(1) http://chicagounbound.uchicago.edu/uclf/vol1989/ iss 1/8 [dostęp: 21.10.2019].

Cross Gary, 1990, A Social History of Leisure since 1600, Venture Publishing, State College, PA.

Csikszentmihalyi Mihaly, 1996, Przeptyw: psychologia optymalnego doświadczenia. Jak poprawić jakość życia, tłum. Magdalena Wajda, Wydawnictwo Studio Emka, Warszawa.

Czajka Stanisław, 1974, Z problemów czasu wolnego, Instytut Wydawniczy CRZZ, Warszawa.

Danecki Jan, 1970, Jedność podzielonego czasu: czas wolny i czas pracy w społeczeństwach uprzemysłowionych, Książka i Wiedza, Warszawa. 
Domański Henryk, 1999, Prestiż, Wydawnictwo Funna, Wrocław.

Domański Henryk, 2015, Czy sa w Polsce klasy społeczne?, Wydawnictwo Krytyki Politycznej, Warszawa.

Domański Henryk, Ostrowska Antonina, Rychard Andrzej, 2000, Jak żyja Polacy, IFIS PAN, Warszawa.

Domański Henryk, Karpiński Zbigniew, Przybysz Dariusz, Straczuk Justyna, 2015, Wzory jedzenia a struktura społeczna, Scholar, Warszawa.

Dumazedier Joffre, 1974, The Sociology of Leisure, Elsevier, Amsterdam.

Durkheim Émile, 1999, O podziale pracy społecznej, tłum. Krzysztof Wakar, Wydawnictwo Naukowe PWN, Warszawa.

Earl Jennifer, Schussman Alan, 2008, Contesting Cultural Control: Youth Culture and Online Petitioning, w: Bennet Lance (red.), Civic Life Online: Learning How Digital Media Can Engage Youth, The MIT Press, Cambridge, MA.

Fajardo Jose Antonio Sanchez, 2019, Exploring the 'Shashification' of Teenage Slang, „English Today", t. 35(3), s. 49-54 (DOI: 10.1017/S0266078418000251).

Fatyga Barbara, 2001, Młodość bez skrzydet: nastolatki w matym mieście: raport $z$ badań $i$ diagnoza sytuacji spoteczno-kulturalnej, ISNS UW, Warszawa.

Fatyga Barbara, 2005, Dzicy z naszej ulicy, OBM UW, Warszawa.

Fatyga Barbara, 2012, Czas dla siebie, w: Stownik teorii żywej kultury (http://ozkultura.pl/ [dostęp: 21.10.2018]).

Filiciak Mirosław, Danielewicz Michał, Halawa Mateusz, Mazurek Paweł, Nowotny Agata, 2010, Młodzi i media. Nowe media a uczestnictwo w kulturze, SWPS, Warszawa.

Gdula Maciej, 2018, Nowy autorytaryzm, Krytyka Polityczna, Warszawa.

Giddens Anthony, 2002, Nowoczesność $i$ tożsamość. „Ja” i społeczeństwo w epoce późnej nowoczesności, tłum. Alina Szulżycka, Wydawnictwo Naukowe PWN, Warszawa.

Goffman Erving, 1981, Człowiek w teatrze życia codziennego, tłum. Helena Datner-Śpiewak, Paweł Śpiewak, Państwowy Instytut Wydawniczy, Warszawa.

Goggin Joyce, 2018, Playbour, Farming and Labour: Work, Play and Boredom (http://www.epheme rajournal.org/contribution/playbour-farming-and-labour [dostęp: 21.10.2019]).

Gross Elisheva, Hardin Curtis, 2007, Implicit and Explicit Stereotyping of Adolescents, „Social Justice Research", t. 20(2), s. 140-160 (DOI: 10.1007/s11211-007-0037-9).

Hargittai Eszter, Walejko Gina, 2008, The Participation Divide: Content Creation and Sharing in the Digital Age, „Information, Communication and Society”, t. 11(2), s. 239-256 (DOI: 10.1080/13691180801946150).

Huizinga Johan, 1998, Homo ludens. Zabawa jako źródło kultury, tłum. Maria Kurecka, Witold Wirpsza, Czytelnik, Warszawa.

Jacyno Małgorzata, 2007, Kultura indywidualizmu, Wydawnictwo Naukowe PWN, Warszawa. Jenkins Henry, 2007, Kultura konwergencji: zderzenie starych i nowych mediów, tłum. Małgorzata Bernatowicz, Mirosław Filiciak, Wydawnictwo Akademickie i Profesjonalne, Warszawa.

Kamiński Aleksander, 1965, Czas wolny ijego problematyka społeczno-wychowawcza, Ossolineum, Wrocław.

Kivel Dana, Kleiber Douglas, 2000, Leisure in the Identity Formation of Lesbian/Gay Youth: Personal, but Not Social, „Leisure Sciences”, t. 22(4), s. 215-232 (DOI: 10.1080/014904099502022 76). 
Krajewski Marek, 2013, Nuda: smart boredom, „Dwutygodnik.com”, wyd. 121, listopad (https://www.dwutygodnik.com/artykul/4885-nuda-smart-boredom.html [dostęp 21. 10.2019]).

Lenhart Amanda, Madden May, 2005, Teen Content Creators and Consumers, Pew Internet and American Life Project, Washington.

MacCannell Dean, 2002, Turysta. Nowa teoria klasy próżniaczej, tłum. Ewa Klekot, Anna Wieczorkiewicz, Muza, Warszawa.

Maffesoli Michel, 2008, Czas plemion. Schytek indywidualizmu w społeczeństwach ponowoczesnych, tłum. Marta Bucholc, Wydawnictwo Naukowe PWN, Warszawa.

Marody Mirosława, 1997, Styl życia jako kategoria opisu socjologicznego, w: Macieja Falkowska (red.),Wartości, praca, zakupy... O stylach życia Polaków, Centrum Badań Opinii Społecznej, Warszawa.

Milner David, 2016, Crunch: The Video Game Industry's Notorious Labour Problem (https://www.g ameinformer.com/b/features/archive/2018/01/16/crunch-the-video-game-industrys-no torious-labor-problem.aspx [dostęp: 21.10.2019]).

Neulinger, John, 1974, The Psychology of Leisure: Research Approaches to the Study of Leisure, Charles C. Thomas, Springfield.

Nielsen Jakob, 2006, The 90-9-1 Rule for Participation Inequality in Social Media and Online Communities (https://www.nngroup.com/articles/participation-inequality [dostęp: 10.09.2020]).

Pyżalski Jacek, 2016, Od paradygmatu ryzyka do paradygmatu szans: prorozwojowe i prospołeczne używanie Internetu przez dzieci i młodzież, w: Maciej Tanaś (red.), Nastolatki wobec internetu, NASK, Warszawa.

Rojek Chris, 1995, Decentering Leisure: Rethinking Leisure Theory, Sage, London.

Rojek Chris, 2000, Leisure and Culture, Palgrave Macmillan UK, London.

Rojek Chris, 2005, Leisure Theory: Principles and Practices, Palgrave Macmillan UK, London.

Rybczynski Witold, 1991, Waiting for the Weekend, Viking Press, New York.

Scraton Sheila, 1992, Shaping Up to Womanhood: Gender and Girls' Physical Education, Open University Press, London.

Siciński Andrzej (red.), 1976, Style życia: koncepcje i propozycje, Państwowe Wydawnictwo Naukowe, Warszawa.

Siemieńska Renata, 2006, Zarządzanie czasem — budżet czasu, w: Bogdan Baran (red.), Krajowy System Monitorowania Równego Traktowania Kobiet i Mężczyzn: raporty eksperckie, t. 1, Scholar, Warszawa.

Stebbins Robert, 2007, Serious Leisure: A Perspective for Our Time, Transaction Publishers, New Jersey.

Szafraniec Krystyna, Boni Michał, 2011, Młodzi 2011, Kancelaria Prezesa Rady Ministrów, Warszawa.

Szlendak Tomasz, 2011, Nic? Aktywność kulturalna i czas wolny na wsi i w matych miastach, w: Izabela Bukraba-Rylska, Wojciech J. Burszta (red.), Zróżnicowanie kultury wsi i małych miast w Polsce, NCN, Kraków.

Sztark Marek, 2016, Kultura średnich $i$ matych miast, Miejska Biblioteka Publiczna, Pieszyce.

Tanaś Maciej, Kamieniecki Wojciech, Bochenek Marcin, Wrońska Agnieszka, Lange Rafał, Fila Mariusz, Loba Bartosz, 2017, Raport. Nastolatki 3.0, NASK, Warszawa. 
Toffler Alvin, 1986, Trzecia fala, tłum. Ewa Woydyłło, Państwowy Instytut Wydawniczy, Warszawa.

Tosenberger Catherine, 2008, Homosexuality at the Online Hogwarts: Harry Potter Slash Fanfiction, „Children's Literature”, t. 36(1), s. 185-207 (DOI: 10.1353/chl.0.0017).

Truszkowska-Wojtkowiak Maria, 2012, Fenomen czasu wolnego, Harmonia, Gdańsk.

Tyszka Andrzej, 1971, Uczestnictwo w kulturze: o różnorodności stylów życia, Państwowe Wydawnictwo Naukowe, Warszawa.

UNICEF, 2012, The State of the World's Children 2012: Children in an Urban World, New York.

Urry John, Larsen Jonas, 2011, The Tourist Gaze 3.0, Sage Publishing, Thousand Oaks.

van Mierlo Trevor, 2014, The 1\% Rule in Four Digital Health Social Networks: An Observational Study (DOI: 10.2196/jmir.29).

Veblen Thorstein, 1998, Teoria klasy próżniaczej, tłum. Janina Frentzel-Zagórska, Muza, Warszawa.

Walvin James, 1978, Leisure and Society 1830-1950, Longman, New York.

Wearing Betsy, 1998, Leisure and Feminist Theory, Sage Publishing, Thousand Oaks.

Weber Max, 1994, Etyka protestancka a duch kapitalizmu, tłum. Jan Miziński, Test, Lublin.

Weber Max, 2002, Gospodarka i społeczeństwo, tłum. Dorota Lachowska, Wydawnictwo Naukowe PWN, Warszawa.

Wells Karen, 2002, Reconfiguring the Radical Other: Urban Children's Consumption Practices and the Nature/Culture Divide, „Journal of Consumer Culture” (https://doi.org/10.1177/1469540 50200200301).

Wells Karen, 2005, Strange Practices: Children's Discourses on Transgressive Unknowns in Urban Public Space, „Childhood”, t. 12(4), s. 495-506 (DOI: 10.1177/0907568205058611).

Wnuk-Lipiński Edmund, 1975, Czas wolny: wspótczesność i perspektywy, Instytut Wydawniczy CRZZ, Warszawa.

Wnuk-Lipiński Edmund, 1981, Budżet czasu, struktura społeczna, polityka społeczna, Ossolineum, Wrocław.

Zarycki Tomasz, 2008, Kapitat kulturowy. Inteligencja w Polsce i Rosji, Wydawnictwa Uniwersytetu Warszawskiego, Warszawa.

Zendle David, Rachel Meyer, Over Harriet, 2019, Adolescents and Loot Boxes: Links with Problem Gambling and Motivations for Purchase, „Royal Society Open Science”, t. 6 (https:// doi.org/10.1098/rsos.190049).

Żbikowska Agata, 2019, Nastolatek jako „trudny klient” w perspektywie przedstawicieli gminnych instytucji kultury, „Społeczeństwo, Edukacja, Język”, t. 9 (DOI: 10.19251/sej/2019.9(8)).

THE FREE TIME OF TEENAGERS

FROM THE PERSPECTIVE OF SOCIOLOGICAL THEORY

Agata Żbikowska

(Warsaw University)

Abstract

This article is an attempt to redefine the concept of free time in such a way as to take into account the nuances of the social determinants of adolescent leis- 
ure. Classic definitions of leisure have emphasized its disinterestedness, voluntary nature, and unproductiveness. Later researchers indicated that the issue was more complex. How people spend their free time is a derivative of their social position and cultural, social, and symbolic capital, and is also often a component of a chosen lifestyle or an element of identity. It is currently believed that how a person spends free time is also influenced by the individual's gender, age, origin, and physical predisposition. In regard to youth leisure, the disappearance of clear divisions between work and rest time seems to be extremely important, especially in two areas: participation in extracurricular activities, and the huge role of smartphones and the Internet in the lives of young people, along with the associated "prosumption," unregulated financial issues (making money online), and many other phenomena.

key words: leisure/free time, lifestyles, identity, teenagers

słowa kluczowe: czas wolny, style życia, tożsamość, nastolatki 